\title{
The Substitution of Avocado Seed Flour to Rice Flour in the Manufacture of Traditional Palembang Food Gandus Cake
}

\author{
$1^{\mathrm{st}}$ Terati \\ Department of Nutrition \\ Poltekkes Kemenkes Palembang \\ Palembang, Indonesia \\ terati_idris@yahoo.co.id
}

\author{
$2^{\text {nd }} M$. Zikrullah L. \\ Department of Nutrition Poltekkes \\ Kemenkes Palembang \\ Palembang, Indonesia \\ muhammadladako@gmail.com
}

\author{
$3^{\text {rd }}$ Marlisa Puspitasari \\ Department of Nutrition \\ Poltekkes Kemenkes Palembang \\ Palembang, Indonesia \\ mrlisps@gmail.com \\ $5^{\text {th }}$ Tri Wahyuni \\ Department of Nutrition \\ Poltekkes Kemenkes Palembang \\ Palembang, Indonesia \\ triwahyuniii95@gmail.com
}

Corresponding author: terati_idris@yahoo.co.id

\begin{abstract}
Avocados (Perseaamericana mill) are plants that thrive in tropical regions like Indonesia and have high antioxidant content. Avocados are usually consumed directly or can be made into juice, with the advancement of science now many avocados are modified into cakes, salads and other processed foods. Some of us only consume meat from the avocado and discard the seeds directly from the avocado. Without us knowing that avocado seeds have many health benefits. Avocado seeds are rich in vitamin $C$, vitamin $B 2$, vitamin $B 3$, protein, and potassium. Avocado seeds can be used and made in the form of flour. Avocado seed flour is one of the alternatives in the main ingredients for making cakes and other processed food ingredients. A barley cake is also a typical food from the city of Palembang. A barren cake made from the main ingredient of rice flour mixed with coconut milk has a soft texture and delicious taste. Aside from being easy to make, ingredients from barren cakes are easy to find and only require a small fee to make. This study aims to determine the effect of avocado seed flour substitutions on organoleptic properties of barren cakes. This study is an experimental study in which the level of substitution of rice flour with avocado seeds as a treatment. There are 3 treatments namely F1 $(25 \%$ avocado seed flour), F2 (50\% avocado seed flour), F3 (75\% avocado seed flour) and F0 (control). Based on the results of statistical tests, avocado seed meal substitution has a significant effect $(P<0.05)$ on the organoleptic yield of the product. $75 \%$ substituted avocado seed cake (F3) is
\end{abstract}

the formula with the highest acceptance compared to other formulas. The characteristics of the barren cake is to have a rather bitter taste, fragrant aroma, somewhat rough texture, and brown in color. The barren cake contains $25.57 \%$ carbohydrates, $6.05 \%$ fat, $3.45 \%$ protein, $63.08 \%$ water content, and $1.85 \%$ ash content.

Keywords: Avocado, Avocado Seed Flour, Gandus Cake.

\section{INTRODUCTION}

Avocado is a very nutritious fruit, contains $3-30$ percent oil with the same composition as olive oil and contains lots of B vitamins [1]. The avocado flesh contains protein, minerals $\mathrm{Ca}, \mathrm{Fe}$, vitamins $\mathrm{A}, \mathrm{B}$, and C [1]. According to the results of the analysis of research by [2]. avocado seeds have a water content of $12.67 \%$, an ash content of $2.78 \%$. Mineral content $0.54 \%$ higher than other fruit seeds. Avocado seeds are a rich source of a complex mix of polyphenolic compounds. Avocado seeds contain 13-18\% of the fruit, and in them contain several biological activities such as antioxidants, antihypertensives, larvicides, fungicides, hypolipidemic, and amoebicidal and giardicidal. Avocado seeds have a wide range of applications in ethno-medicine, from treatment for diarrhea, dysentery, toothaches, intestinal parasites 
skin and beauty treatments. Several studies have recently proven that phytochemical screening of avocado seeds (Persea americana Mill) using ethanol extract, shows that avocado seeds contain secondary metabolite compounds, including: alkaloids, tannins, lavonoids, polyphenols, saponins, triterpenoids, quinones, monoterpenoids and sesquiterpenoid [3]. Gandus cake is one of the traditional Palembang foods. This gandus cake is no less popular with pempek, and this gandus cake is popular with many people, especially in the Palembang area. Besides being easy to make, the ingredients of this gandus cake are easily available such as rice flour, coconut milk and salt. Gandus cake is usually consumed as a snack and a friend to drink coffee or tea. Gandus cake can be found in traditional markets in Palembang, apart from being easy to find, the price is also relatively cheap.

\section{METHOD}

The ingredients used in the study of the avocado seed flour gandus cake included rice flour and avocado seed flour. Additional ingredients needed are salt and coconut milk. The equipment used in this research is a dough basin, gas stove, steamer, blender, plastic mold, wooden spoon, stainless steel spoon, plate, cutting board, tissue, digital scale, plastic gloves. This research is an experimental study using a non-factorial Completely Randomized Design (CRD). The treatment under study includes the proportion of combining the following ingredients:

Table 1. Combination of Ingredients for Making Gandus Cake Ingredients ( Formula (gram)

\begin{tabular}{lllll}
\hline & F0 & F1 & F2 & F3 \\
Rice Flour & 100 & 75 & 50 & 25 \\
\hline Avocado seed Flours & 0 & 25 & 50 & 75 \\
\hline Salt & 5 & 5 & 5 & 5 \\
\hline Coconut Milk & 200 & 200 & 200 & 200 \\
\hline
\end{tabular}

Data collection methods used in this study include organoleptic tests and chemical tests. Organoleptic test or preference test is a test of the material being tested. The organoleptic test is used for testing where the panelist expresses a happy or unhappy response to the properties of the material being tested. The panelists used were 30 semi-trained panelists. The chemical test aims to determine the nutritional value of the gandus cake with the substitute ingredient for avocado seed flour. The results of this method are
Very influential from the assessment of panelists, so that the panelists who must assess it are trained panelists in order to get good results.

\section{RESULTS AND DISCUSSION}

Organoleptic tests were carried out on the gandus cake formula F0 and the three avocado seed powder gandus cake formulas F1, F2, and F3. Then after the data obtained from the organoleptic test results were analyzed using a non-parametric test (Friedman test) to see the average level of acceptance in the form of a ranking and the effect of adding avocado seed flour to the gandus cake.

Graph 1: Average Acceptance of Gandus Cake with Addition of Avocado Seed Flour

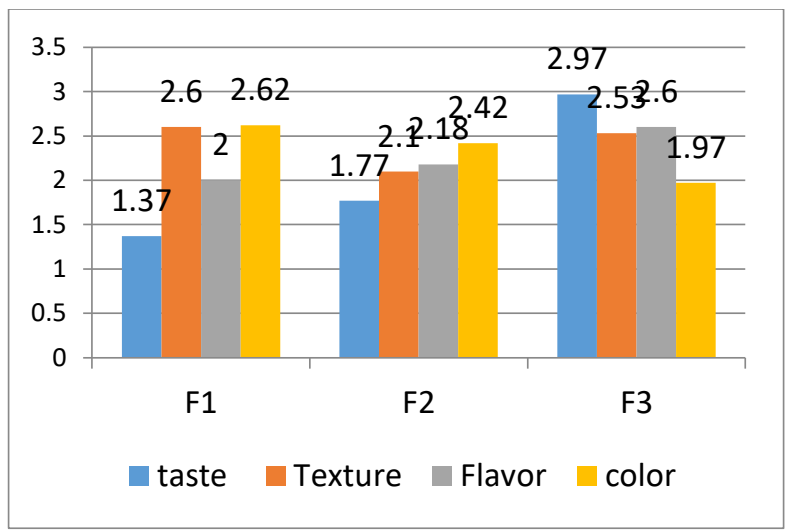

\section{A. Taste}

Based on the results of the organoleptic test, the taste of the sample with code F3 was preferred by respondents / panelists of 2.97 compared to the sample codes F1 and F2, namely 1.37 and 1.77 . The taste in the sample with code F3 was liked by many panelists / respondents because it had a gandus cake taste that resembled gandus cakes in general due to the addition of avocado seed flour (TBA) which was not too much. Because, the addition of TBA affects the taste of the gandus cake. The gandus cake tastes a little more bitter if TBA is more dominant than ordinary rice flour. Based on the theory, TBA has a predominantly bitter taste, but if it is added with coconut milk, the bitter taste can be lost even though it is not completely lost.

\section{B. Texture}

Based on the results of the organoleptic test, the texture of the sample with code F1 was denser and more acceptable to respondents / panelists, namely 2.60 compared to the softer F2 and F3 codes, namely 2.10 and 2.53. Based on the test, F1 has a denser texture. The addition of Avocado Seed Flour (TBA) 
causes the texture to be softer than the dry texture without the addition of TBA. This is due to the nature of rice flour which binds the dough more than TBA. Rice flour contains higher starch than TBA so that the F1 gandus has a tougher texture.

\section{Flavor}

Based on the results of the organoleptic test, the respondents / panelists preferred the aroma in the sample with code F3, namely 2.60 because the aroma of Avocado Seed Flour (TBA) was more dominant than the F1 and F2 codes, namely 2.00 and 2.18. Aroma is an organoleptic attribute that can be assessed by the sense of smell. The attributes of the scent of gandus range from very unpleasant to very fragrant. The results of the organoleptic assessment showed that F3 gandus had a fragrant aroma compared to F1 and F2. The difference in aroma that is found in gandus occurs because the substitution of avocado seed flour will affect the aroma because of the unpleasant characteristics of avocado bji flour.

\section{Color}

Based on the results of the organoleptic test carried out, the color in the sample coded F1 was more dominant because it was not the same as the color of the previous gandus cake, which was 2.62 , while the samples with code F2 and F3 were 2.42 and 1.97. Supported by the opinion of [4]. food ingredients containing phenolic compounds can experience enzymatic browning. The colors in the samples coded F1 are much more striking than the colors in the sample codes F2 and F3 because the addition of TBA is more dominant than in the samples coded F2 and F3. The color in the F1 sample affected the unattractive taste because the gandus cake was bitter and a little hard.

Table 2. Nutritional Value of Avocado Seed Gandus Cake with Proximate test

\begin{tabular}{ccccccc}
\hline Code & $\begin{array}{c}\text { Water } \\
(\%)\end{array}$ & $\begin{array}{c}\text { Ash } \\
(\%)\end{array}$ & $\begin{array}{c}\text { Fat } \\
(\%)\end{array}$ & $\begin{array}{c}\text { Protein } \\
(\%)\end{array}$ & $\begin{array}{c}\text { KH } \\
(\%)\end{array}$ & $\begin{array}{c}\text { Antioksidan } \\
(\%)\end{array}$ \\
\hline F1 & 60,46 & 0,77 & 4,67 & 4,05 & 30,05 & 7373 \\
\hline F2 & 58,20 & 0,54 & 5,10 & 3,62 & 32,45 & 14163 \\
\hline F3 & 63,08 & 1,85 & 6,05 & 3,45 & 25,57 & 22018 \\
\hline
\end{tabular}

\section{Water Content of Gandus Cake with Avocado Seed Flour}

From the results of laboratory examinations, it was found that the water content for the F1 code was $60.46 \%$, F2 was $58.20 \%$, and F3 was $63.08 \%$. It turned out that the one with the lowest water content was the sample with the F2 code, and the one with the highest water content was the sample with the F3 code. According to [5]. water activity (aw) is free water found in foodstuffs that can be used for the growth of microorganisms. The higher the aw value, the gandus has a shorter shelf life. The moisture content of the sample with code $\mathrm{F} 3$ proves that it is in great demand by panelists / respondents because the texture of the cake is softer than before. It's just that based on the theory above, the moisture content of the sample with code F3 has a short shelf life

\section{Ash Content of Gandus Cake with Avocado Seed Flour}

From the results of laboratory examinations, it was found that the ash content for the F1 code was $0.77 \%$, $\mathrm{F} 2$ was $0.54 \%$, and $\mathrm{F} 3$ was $1.85 \%$. It turns out that the one with the lowest ash content is the sample with the F2 code, and the highest ash content is the sample with the F3 code. Ash content has something to do with the mineral content of a material, measuring the ash content aims to determine the amount of mineral content contained in food / food [6].

\section{Carbohydrate Content of Gandus Cake with Avocado Seed Flour}

From the results of laboratory examinations, it was found that carbohydrate content for F1 code was $30.05 \%$, F2 was $32.45 \%$, and F3 was $25.57 \%$. It turns out that the one with the lowest carbohydrate content is the sample with the F3 code, and the highest carbohydrate content is the sample with the F2 code. Carbohydrates have the main function of providing the body's energy needs. However, carbohydrates function not only as a source of energy, but also for other functions in the continuity of metabolic processes in the body [4]. The carbohydrate content in the sample with code F2 is higher than the other samples because the ratio between TBA and rice flour is 1: 1

\section{Protein Content of Gandus Cake with Avocado Seed Flour}

From the results of laboratory examinations, it was found that the protein content for F1 code was $4.05 \%$, $\mathrm{F} 2$ was $3.62 \%$, and F3 was $3.45 \%$. It turned out that the one with the lowest protein content was the sample coded F3, and the highest protein content was the sample coded F1. The protein content in the sample with code F1 was higher than the other samples because the addition of TBA was more than rice flour. But the addition of TBA was not very attractive to the panelists because TBA had a bitter taste. 


\section{Fat Content of Gandus Cake with Avocado Seed Flour}

From the results of laboratory examinations, it was found that the fat content for the F1 code was $4.67 \%$, $\mathrm{F} 2$ was $5.10 \%$, and $\mathrm{F} 3$ was $6.05 \%$. It turned out that the one with the lowest fat content was the sample coded F1, and the highest fat content was the sample coded F3. The fat content in the sample with code F3 was higher due to the small addition of TBA and was dominated by rice flour and coconut milk. The addition of coconut milk made the taste of the F3 sample more desirable. As is known, coconut milk itself has a high enough fat content, which is 23.84 grams per 100gr.

\section{Antioxidant Levels of Gandus Cake with Avocado Seed Flour}

From the results of laboratory examinations, it was found that antioxidant levels for the code F1 7373 IC 50 ppm, F2 14163 IC 50 ppm and F3 22018 IC 50 ppm. It turned out that those with the lowest levels of antioxidants were samples with code F1 and the highest levels of antioxidants, namely samples with code F3. Antioxidants are very easily oxidized, so free radicals will oxidize antioxidants and protect other molecules in cells from damage caused by oxidation by free radicals or reactive oxygen [7]. Samples that had the highest levels of antioxidants were those with the most additional BTA and had good health benefits.

\section{CONCLUSION}

1. Based on the organoleptic results (acceptability) of the gandus cake using avocado seed flour, the results of the F3 formula were very popular, namely in terms of taste and flavor.

2. Based on the chemical test, it is known that the nutritional value of gandus cake using avocado seed flour has a better nutritional value, namely in the F3 formula; water content $63.08 \%$, ash content $1.85 \%$, fat content $6.05 \%$, protein content $3.45 \%$, KH content $25.57 \%$ and antioxidant 22018 IC 50 ppm.

\section{ACKNOWLEDGMENT}

The author is the greteful to the Institute of Reserch and Community Service at Polytechnic health ministry of health Palembang for helping to fund this research.

\section{REFERENCES}

[1] Andi S. Penggunaan Buah Alpukat Untuk Rambut. Bogor: Gramedia; 2013.

[2] A. R, Lisanti E. Ekstraksi dan Karakteristik Senyawa Fenolik dari Biji Alpukat (Persea Americana Mill.). Bandung: PATPI National Seminar Proceeding; 2007.

[3] Marlinda M, Sangi MS, Wuntu AD. Analisis Senyawa Metabolit Sekunder dan Uji Toksisitas Ekstrak Etanol Biji Buah Alpukat ( Persea americana Mill .) 2012;1:24-8.

[4] FG. W. Food Chemistry and Nutrition. Jakarta. Jakarta: Gramedia Pustaka Utama; 2004.

[5] S S, S S, ST I. Teknologi Pengemasan Pangan. Bogor: PAU Pangan dan Gizi. Institut Pertanian Bogor; 1989.

[6] Zuhrotun A. Aktivitas Antidiabetes Ekstrak Etanol Biji Buah Alpukat (Persea americana Mill). Universitas Padjajaran, 2007.

[7] Asri Werdhasari. Peran Antioksidan Bagi Kesehatan. J Biomedik Medisiana Indones 2014;3:59-68. 